\title{
Molecular Identification of a Velogenic Newcastle Disease Virus Strain Isolated from Egypt
}

\author{
Shakal M. ${ }^{1^{*}}$, Mira Maher ${ }^{2}$, Abdulrahman S. Metwally², Mohammed A. AbdelSabour ${ }^{3}$, Yahia M. Madbbouly ${ }^{3}$ \\ and Gehan Safwat ${ }^{2}$. \\ ${ }^{I}$ Department of Poultry Diseases, Faculty of Veterinary Medicine, Cairo University, 12211 Giza, Egypt. \\ ${ }^{2}$ Faculty of Biotechnology, October University for Modern Sciences and Arts, MSA, $6^{\text {th }}$ of October City, Egypt. \\ ${ }^{3}$ Veterinary Serum and Vaccine Research Institute, VSVRI, ARC, Abbassia, Cairo 11381, Egypt. \\ "Corresponding author's Email: shakal2000@ gmail.com; ORCID: 0000-0002-1625-7324
}

Received: 14 Feb. 2020 Accepted: 16 Mar. 2020

\begin{abstract}
Newcastle Disease Virus (NDV) is still a major concern for the Egyptian poultry industry in spite of the mass vaccination programs implemented from a long years ago. The current study aimed to carry out the molecular identification of surface glycoprotein genes of NDV field strain isolated from the Giza governorate, Egypt. Tracheae were collected from 10 broilers NDV-vaccinated chicken flocks (at least three samples from each flock) suffering from mild to moderate respiratory symptoms; with mortalities varying from 10-40\% during October 2019. Only five samples showed HA positive activity after propagation in specific pathogen-free embryonated chicken eggs and only one sample was positive for Avian avulavirus 1 by real-time reverse transcription-PCR. Sequencing for the cleavage site of the $\mathrm{F}$ protein gene of the positive isolate showed the typical known sequence of velogenic NDV strains $\left({ }_{112} R_{R Q K R F}{ }_{117}\right)$. Phylogenetic analysis of both $\mathrm{F}$ and $\mathrm{HN}$ genes showed high similarity and close relation to Chinese strains of Genotype VII and more specifically subtype VIId, suggesting the role of migratory wild birds in NDV evolution in Egypt. In conclusion, further epidemiological and surveillance studies are strongly recommended to define the exact role of migratory wild birds in NDV evolution in Egypt.
\end{abstract}

Keywords: Broilers, Newcastle Disease, Poultry industry, Velogenic

\section{INTRODUCTION}

Newcastle Disease (ND) is one of the most important viral diseases affecting poultry which is caused by Avian avulavirus 1 (APMV-1) (Abd El Aziz et al., 2016). The natural hosts of ND virus (NDV) include chickens, turkeys, ducks, geese, pigeons, quail, pheasants, guinea fowl, ostriches, and several species of wild birds (Wang et al., 2015).

ND as an acute viral infectious disease affects domestic poultry regardless of gender and age (Saad et al., 2017) and causes great economic losses, especially in developing countries (Westbury, 2001). Production inefficiencies are considered as a greater concern compared to mortality losses in breeders and layers flocks while mortalities usually reported to be more significant in broilers (Shahid Mahboob et al., 2020). Many NDV outbreaks were reported in the past years around the world, as in Japan (Mase et al., 2002), in Brazil (Marks et al., 2014), in China (Kang et al., 2014), in South America (Diel et al., 2012) and in Malaysia (Jaganathan et al.,
2015). NDV was recorded in Egypt since 1942 (Daubeny and Mancy, 1947) and has been reported ever since. (Hussein et al., 2000; Mohamed et al., 2011; Selim et al., 2018). Recently in Egypt, NDV outbreaks have been reported in both vaccinated and non-vaccinated flocks (Abd El Aziz et al., 2016; Ewies et al., 2017). A subclinical infection manifested by respiratory, intestinal, and nervous symptoms, with mortalities up to $100 \%$ may be a result of NDV infection according to virus strain pathogenicity in infected birds. Based on the pathogenicity of the virus, NDV strains can be categorized into three main types; lentogenic, mesogenic, and velogenic strains. NDV can be classified into two classes; class I and class II. NDV isolates of class I are grouped into one genotype, whereas NDV isolates of class II are grouped into at least eighteen genotypes, some with subgenotypes. Genotype VII viruses are responsible for the fourth panzootic that has spread from Asia, Africa, Europe, and has even been isolated in South America, which continues today (Dimitrov et al., 2016). The NDV is an enveloped virus that has a linear, single-stranded RNA genome of negative 
polarity; with a genome length of about $15.2 \mathrm{~kb}$ (Aldous et al., 2003; Ashraf et al., 2016). The genome of NDV consists of $15,186,15,192$ nucleotides or 15,198 nucleotides that contains six genes coding six structural and two non-structural proteins including an RNAdirected RNA polymerase (L), hemagglutininneuraminidase protein $(\mathrm{HN})$, fusion protein $(\mathrm{F})$, matrix protein $(\mathrm{M})$, phosphoprotein $(\mathrm{P})$, and nucleoprotein $(\mathrm{N})$. Both $\mathrm{F}$ with $\mathrm{HN}$ proteins play a collective role in NDV infection prosses. The fusion protein is the most important key in the NDV virulence determining process (Peeters et al., 1999). Mutations affecting NDV viral genome which alter its biological properties and virulence, in addition to altered immunity, and improper vaccination processes can increase the incidence of NDV outbreaks in vaccinated flocks (Kattenbelt et al., 2006). Virulence of ND can be distinguished on the basis of the cleavage site sequence of the F protein (Selim et al., 2018). HN is one of the membrane glycoproteins, through its neuraminidase (NA) activity it mediates attachment to sialic acid-containing receptors (Wang et al., 2015). Recently, the molecular identification and phylogenetic analysis of any new NDV isolates become an important and usual approach to find out which of the applied control measures needs to be improved (Fringe et al., 2012; Hassan et al., 2016). Sequence analysis of mainly $\mathrm{F}$ and of $\mathrm{HN}$ proteins genes two surface glycoproteins- is wildly used for molecular identification of NDV isolates. Brevity, the current applied NDV vaccination programs consist of live and/or inactivated genotype I or II NDV or genetically modified vaccines depending on flock age and type.

In the present study, analysis of nucleotides sequences of $\mathrm{F}$ and $\mathrm{HN}$ genes were done for a recently isolated NDV strain obtained from samples collected from different chicken flocks showing mild to severe respiratory symptoms with variable mortality rates in Giza governorate, Egypt.

\section{MATERIALS AND METHODS}

\section{Ethical approval}

Institutional, national, and international animal care guidelines were followed.

\section{Sampling and samples history}

Tracheae (at least three samples from each flock) from 10 freshly dead broilers, NDV vaccinated chicken flocks suffering from mild to moderate respiratory symptoms; with mortalities varying from 10 to $40 \%$ as well as a range of NDV indicative postmortem lesions at
Giza governorate during October of 2019. Tracheae from the same flock kept together for isolation. Samples history mentioned in Table 1.

Table 1. History of flock sampled in the present study

\begin{tabular}{lcccc}
\hline Sample & $\begin{array}{c}\text { Birds } \\
\text { No/Flock }\end{array}$ & $\begin{array}{c}\text { Mortalities } \\
(\%)\end{array}$ & $\begin{array}{c}\text { Age of } \\
\text { birds } \\
(\mathbf{d a y})\end{array}$ & NDV vaccination \\
\hline S1 & 10,000 & $12.5 \%$ & 35 & \\
S2 & 8,000 & $14 \%$. & 55 & \\
S3 & 11,000 & $37.6 \%$ & 24 & Twice, live LaSota \\
S4 & 4,000 & $35.8 \%$. & 26 & \\
S5 & 15,000 & $22.4 \%$. & 22 & \\
S6 & 2,000 & $10.7 \%$. & 23 & \\
\hline S7 & 1,000 & $34.5 \%$ & 35 & Once, live LaSota \\
\hline S8 & 3,000 & $21.3 \%$. & 40 & \\
S9 & 4,000 & $39.1 \%$. & 41 & Twice, live LaSota \\
S10 & 12,000 & $35.7 \%$. & 33 & \\
\hline
\end{tabular}

\section{Isolation}

Virus isolation was done from tracheal swabs after immersion in Phosphate-Buffered Saline (PBS) mixed with gentamycin antibiotic $(50 \mu \mathrm{g} / \mathrm{ml})$ and mycostatin (1000 units $/ \mathrm{mL}$ ). Swabs from different birds from the same flock were immersed in the same PBS solutions. Samples were named numerically as sample 1 (S1): sample 10 (S10).

PBS-containing samples were clarified by centrifugation at $5000 \mathrm{rpm}$ for 15 minutes. A $200 \mu \mathrm{l}$ of supernatant fluid from each sample was inoculated into the allantoic cavity of five 10-day-old Specific Pathogen Free Embryonated Chicken Eggs (SPF-ECE). Allantoic fluid from each egg was harvested 3 to 5 days post-inoculation and was tested for hemagglutination (HA) activity by rapid slide HA test. HA negative samples were submitted for two blind passages of SPF-ECE. Collectively, samples that showed HA positive activity were kept for further molecular identification (OIE manual, 2018).

\section{Viral RNA extraction}

Viral RNA from HA positive allantoic fluid was extracted using Pure Link® (Invitrogen, USA) RNA Mini Kit following the manual's instruction.

\section{Real-time reverse transcription-polymerase chain reaction}

Real-time Reverse Transcription PCR (RT-qPCR) was performed in one step. Using TOPreal ${ }^{\mathrm{TM}}$ One-step SYBR Green with low ROX - RT qPCR Kit (Enzynomics, Korea) according to the manufacturer's instructions and 
using the CFX96 Touch real-time PCR detection system (Bio-Rad Laboratories, USA). Primers used were designed according to Wise et al. (2004) which are specific for the matrix protein gene of APMV-1 viruses selected from a conserved region of the $\mathrm{M}$ gene (Table 2).

The thermal conditions were as follows; reverse transcription at $50^{\circ} \mathrm{C}$ for 30 mins followed by 10 mins at $95{ }^{\circ} \mathrm{C}$ for reverse transcriptase inactivation and initial denaturation. Then, followed by 40 amplification cycles of $95{ }^{\circ} \mathrm{C}$ denaturation for $5 \mathrm{~s}, 52^{\circ} \mathrm{C}$ annealing for $10 \mathrm{~s}$, and 60 ${ }^{\circ} \mathrm{C}$ extension for $30 \mathrm{~s}$.

Melting curve analysis was performed to determine the specificity of amplification as follows: $95^{\circ} \mathrm{C}$ denaturation for $10 \mathrm{~s}, 65^{\circ} \mathrm{C}$ annealing for $5 \mathrm{~s}$, and heating to $95{ }^{\circ} \mathrm{C}$ with an increment $0.5{ }^{\circ} \mathrm{C}$ for $0.05 \mathrm{~s}$.

The melting temperature $(\mathrm{Tm})$ of melting curves and $\mathrm{Cp}$ values were calculated using the Bio-Rad CFX manager 3.1 software (Figure 1).

Table 2. Primers used for Newcastle disease virus detection using RT-qPCR.

\begin{tabular}{lc}
$\begin{array}{l}\text { Primer } \\
\text { Name }\end{array}$ & Sequence \\
\hline F Primer & 5'-AGTGATGTGCTCGGACCTTC-3' \\
R primer & 5'-CCTGAGGAGAGGCATTTGCTA-3' \\
\hline
\end{tabular}

\section{$F$ and $\mathrm{HN}$ genes amplification}

Positive NDV RNA samples (by RT-qPCR) samples were subjected to one-step RT-PCR using SuperScript ${ }^{\text {TM }}$ III One-Step RT-PCR System with Platinum ${ }^{\text {TM }}$ Taq DNA Polymerase according to the manufacturer's instructions to amplify full-length $\mathrm{F}$ protein gene and $\mathrm{HN}$ protein gene using two sets of primes kindly provided by Dr. Mohammed Rohaim, Virology Department, Cairo University, Egypt (Table 3) and using the ProFlex PCR thermal cycler (Applied biosystem, USA).

Thermal amplification conditions were as follows; reverse transcription at $50{ }^{\circ} \mathrm{C}$ for $30 \mathrm{~min}$ followed by initial denaturation for $2 \mathrm{~min}$ at $94{ }^{\circ} \mathrm{C}$. Then followed by 40 cycles of denaturation at $94{ }^{\circ} \mathrm{C}$ for $15 \mathrm{~s}$, annealing at 65 ${ }^{\circ} \mathrm{C}$ for $30 \mathrm{~s}$ for $\mathrm{F}$ gene while $51{ }^{\circ} \mathrm{C}$ for $30 \mathrm{~s}$ for $\mathrm{HN}$ gene, and extension at $68{ }^{\circ} \mathrm{C}$ for $120 \mathrm{~s}$ followed by one cycle of final extension at $68^{\circ} \mathrm{C}$ for $5 \mathrm{~min}$.

PCR products were analyzed by agarose gel electrophoresis (1\%) and then purified using a QIAquick Gel Extraction Kit (Qiagen) following the manufacturer's instructions.
Table 3. Primers used for $\mathrm{F}$ and $\mathrm{HN}$ genes amplification and sequencing.

\begin{tabular}{lcc}
\hline $\begin{array}{l}\text { Target } \\
\text { gene }\end{array}$ & $\begin{array}{l}\text { Primer } \\
\text { Name }\end{array}$ & Sequence \\
\hline $\begin{array}{l}\text { F protein } \\
\text { gene }\end{array}$ & Fus-F & 5'-ATGGGCTCCAAACTTTCT-3' \\
\hline $\begin{array}{l}\text { HN } \\
\text { protein } \\
\text { gene }\end{array}$ & Fus-R & 5'-CATGCTCTTGTAGTGGCTCTC-3' \\
\hline
\end{tabular}

\section{Sequencing}

Sequencing of the purified RT-PCR products was done by the Bigdye Terminator V3.1 cycle sequencing kit (Perkin- Elmer, Foster City, CA) and Applied Biosystems 3130 genetic analyzer machine (ABI, USA).

\section{Genetic alignment}

The quality of obtained $\mathrm{F}$ and $\mathrm{HN}$ genes sequences were checked, assembled, edited using Bioedit software version 7.0.4.1 (Hall, 1999), and submitted to GenBank using BankIt tool of the GenBank (http://www.ncbi.nlm.nih.gov/WebSub/?tool=genbank), with accession numbers MN905162 and MN905163, respectively.

\section{Phylogenetic analysis}

The tree was constructed using the neighbor-joining method; bootstrapping at 500 repeats using Mega 6 software version 7.0.26 (Tamura et al., 2013).

\section{RESULTS}

\section{Hemagglutination activity}

After three blind passages only S3, S4, S7, S9, and S10 samples were positive for hemagglutination activity. S7 and S10 were positive for HA after the $1^{\text {st }}$ egg passage, $\mathrm{S} 3$, and $\mathrm{S} 4$ were positive for HA after the $2^{\text {nd }}$ egg passage, and $\mathrm{S} 9$ was positive for $\mathrm{HA}$ after the $3^{\text {rd }}$ egg passage. RNA from 5 positive HA samples were sent for one-step RTqPCR.

\section{NDV detection by RT-qPCR}

Only S4 was positive for Avian avulavirus 1 by RTqPCR with a threshold cycle (CT) of 29.34 with a starting quantity of $3.033 \log 10$ in comparison with a standard curve (Figure 2) with melting peak at $79{ }^{\circ} \mathrm{C}$ (Figure 3 and 4). 


\section{Amplification of full $\mathrm{F}$ and full $\mathrm{HN}$ proteins genes by RT-PCR}

RT PCR products gel electrophoresis revealed the expected and correct size bands for full-length $\mathrm{F}$ and $\mathrm{HN}$ proteins genes.

\section{Genetic and phylogenetic analysis \\ $F$ protein gene}

Blasting of sequence results obtained for the full $\mathrm{F}$ protein gene showed similarities with Chinese genotype VII strains with similarities varying from $95.5 \%$ to 97.28\% and with many Egyptian isolates varying from $94.5 \%$ to $95.5 \%$. The phylogenetic tree of the full $\mathrm{F}$ protein gene showed that $\mathrm{S} 4$ isolate is closely related to genotype VII subtype D (Figure 5).

\section{$\mathrm{HN}$ protein gene}

Blasting of sequence results obtained for the full $\mathrm{HN}$ protein gene showed similarities with Chinese genotype VII strains with similarities varying from $95.69 \%$ to $98.72 \%$ and with some Egyptian isolates varying from $94.9 \%$ to $95.45 \%$ The phylogenetic tree of the full $\mathrm{HN}$ protein gene showed that $\mathrm{S} 4$ isolate is closely related to the Chinese genotype VII (Figure 6). Three-dimensional structure of $\mathrm{F}$ and $\mathrm{HN}$ monomer for $\mathrm{S} 4$ isolate was created by SWISS-Model modeling online server and visualized by PyMOL program version 2.3.4 (Figure 7 and 8).

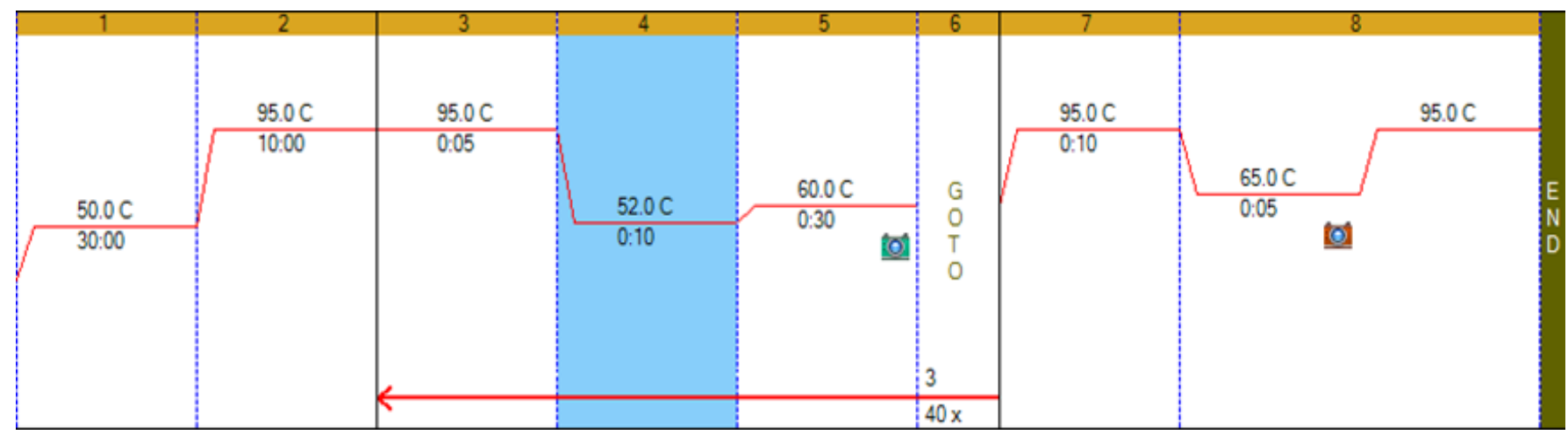

Figure 1. Thermal conditions applied at RT-qPCR and for the melting curve.

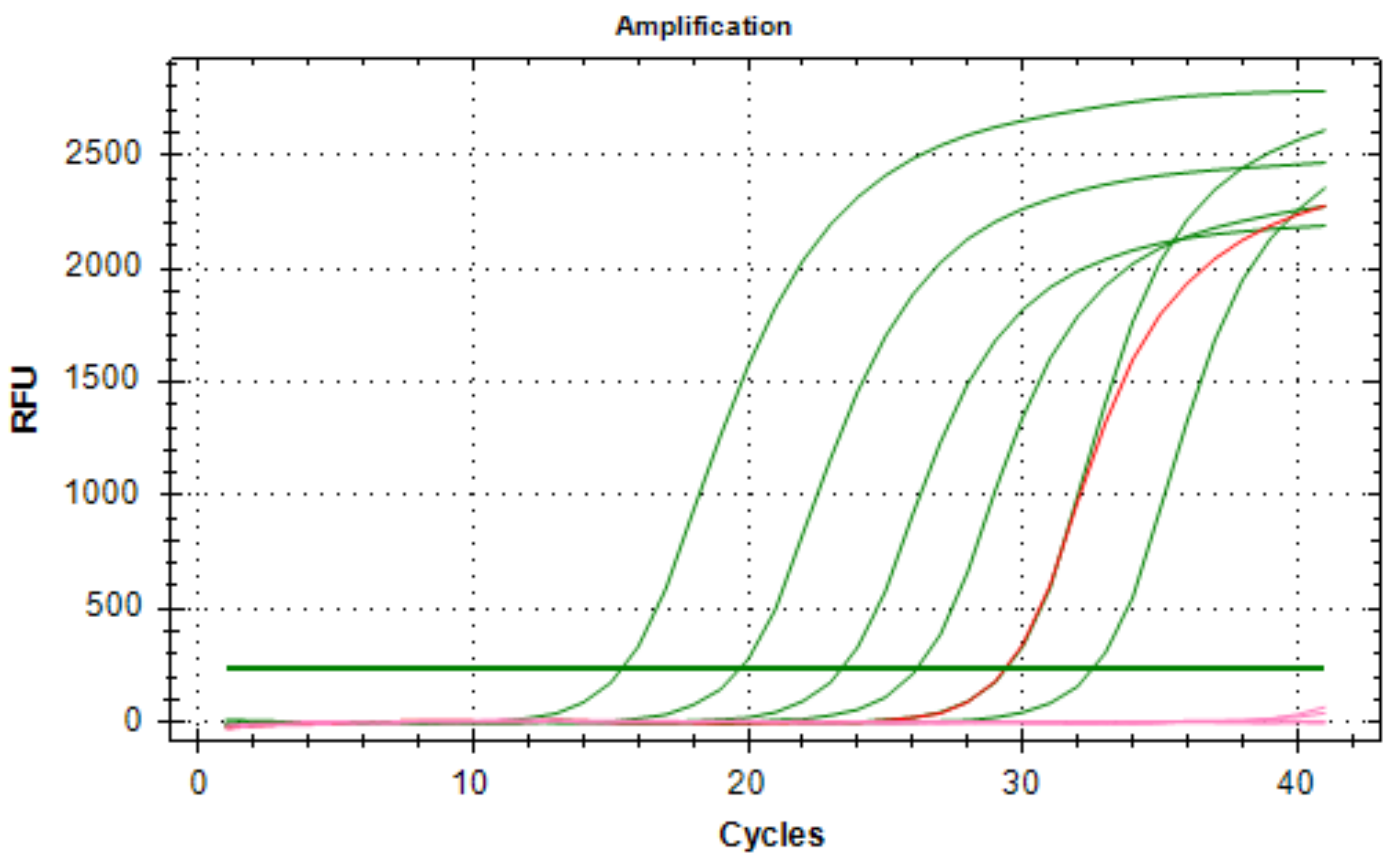

Figure 2. Threshold cycles of tested samples, green lines represent positive control samples (standard curve samples), the red line represents positive for Avian avulavirus sample (S4) appeared after 29.34 CT, and pink lines represent the negative for Avian avulavirus samples. 


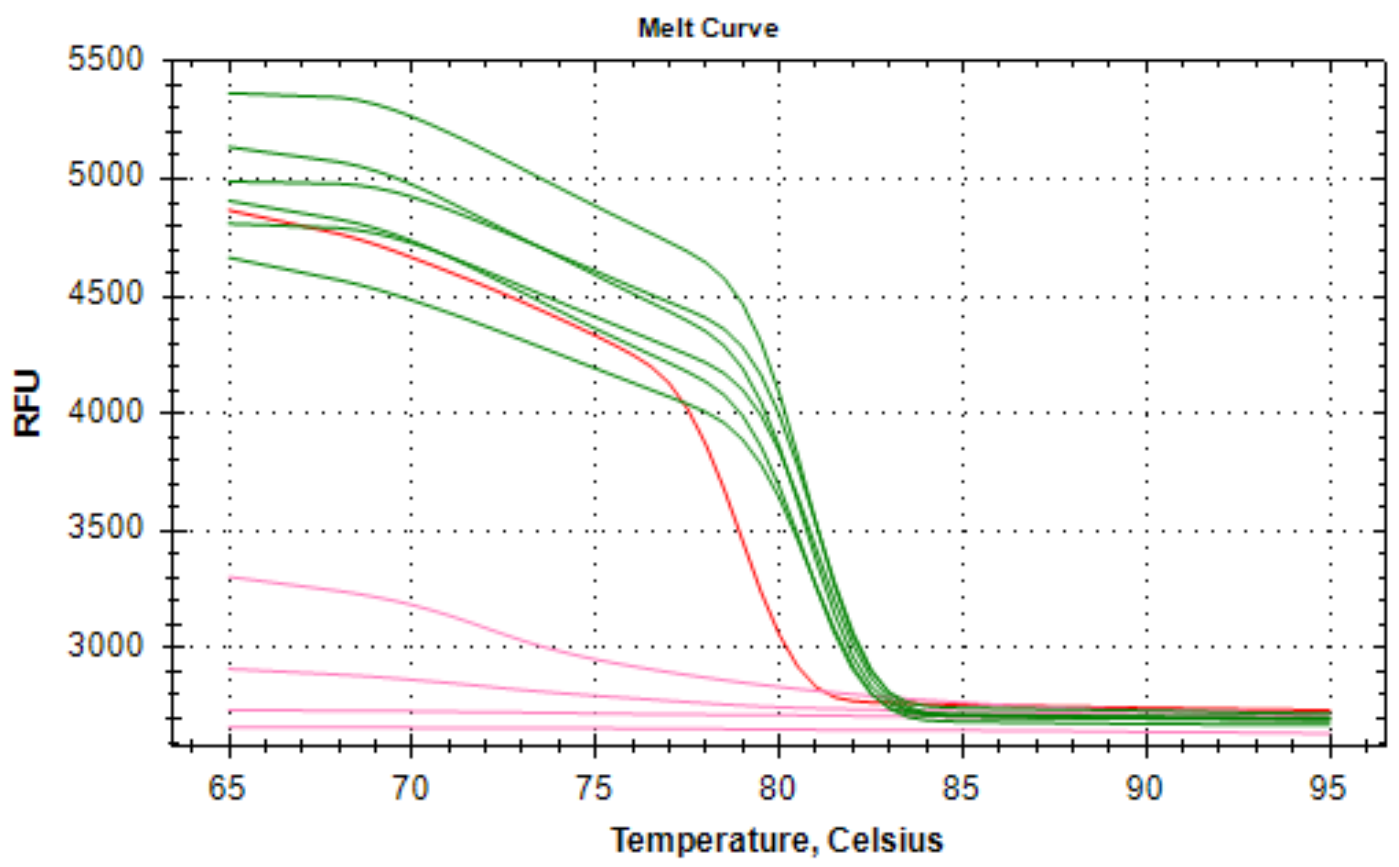

Figure 3. Melting curve of tested samples, green lines represent positive control samples (standard curve samples), the red line represents positive for Avian avulavirus sample (S4), and pink lines represent the negative for Avian avulavirus samples.

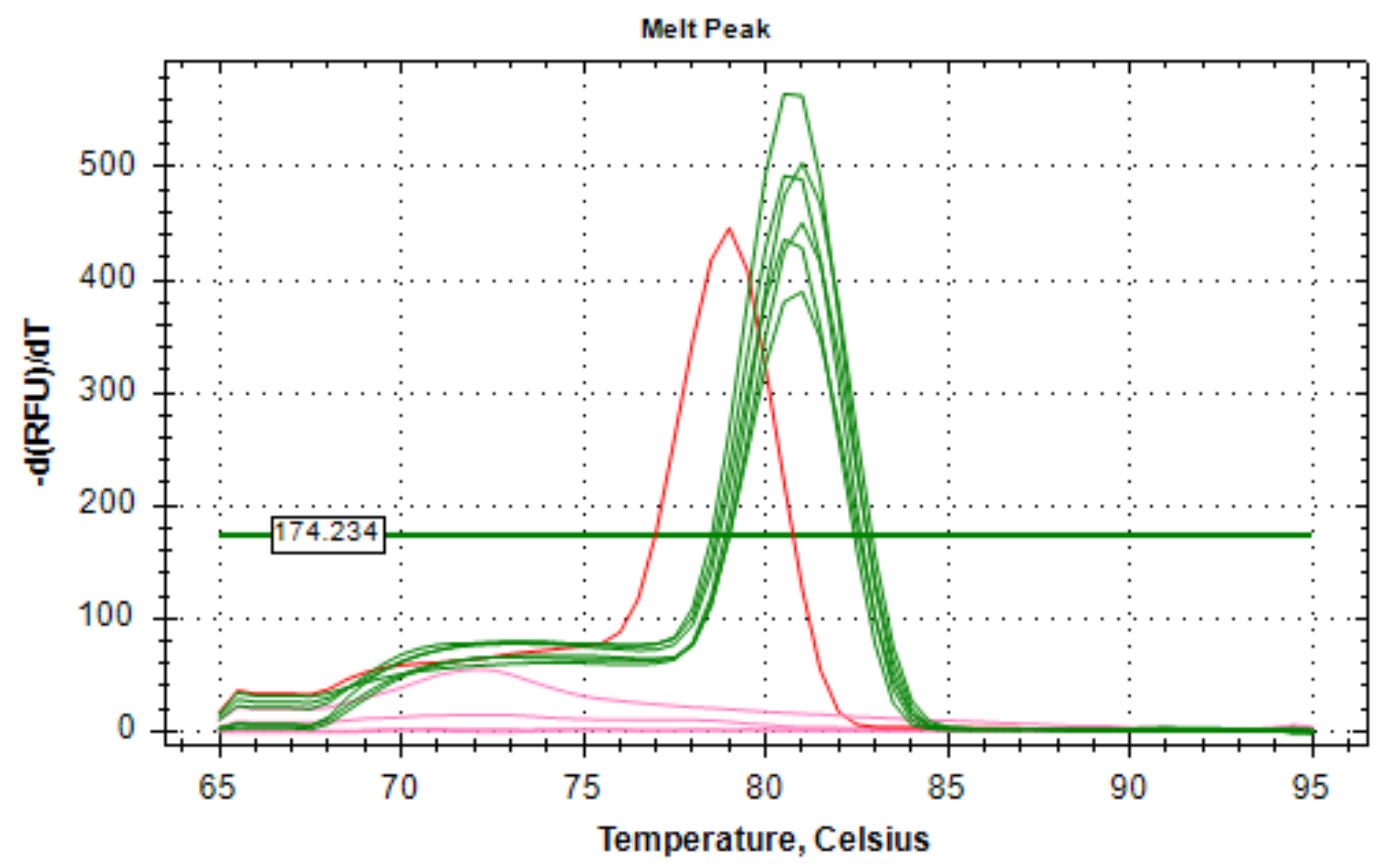

Figure 4. Melting peak of tested samples, green lines represent positive control samples (standard curve samples), the red line represents positive for Avian avulavirus sample (S4) showed a different melting peak, and pink lines represent the negative for Avian avulavirus samples. 


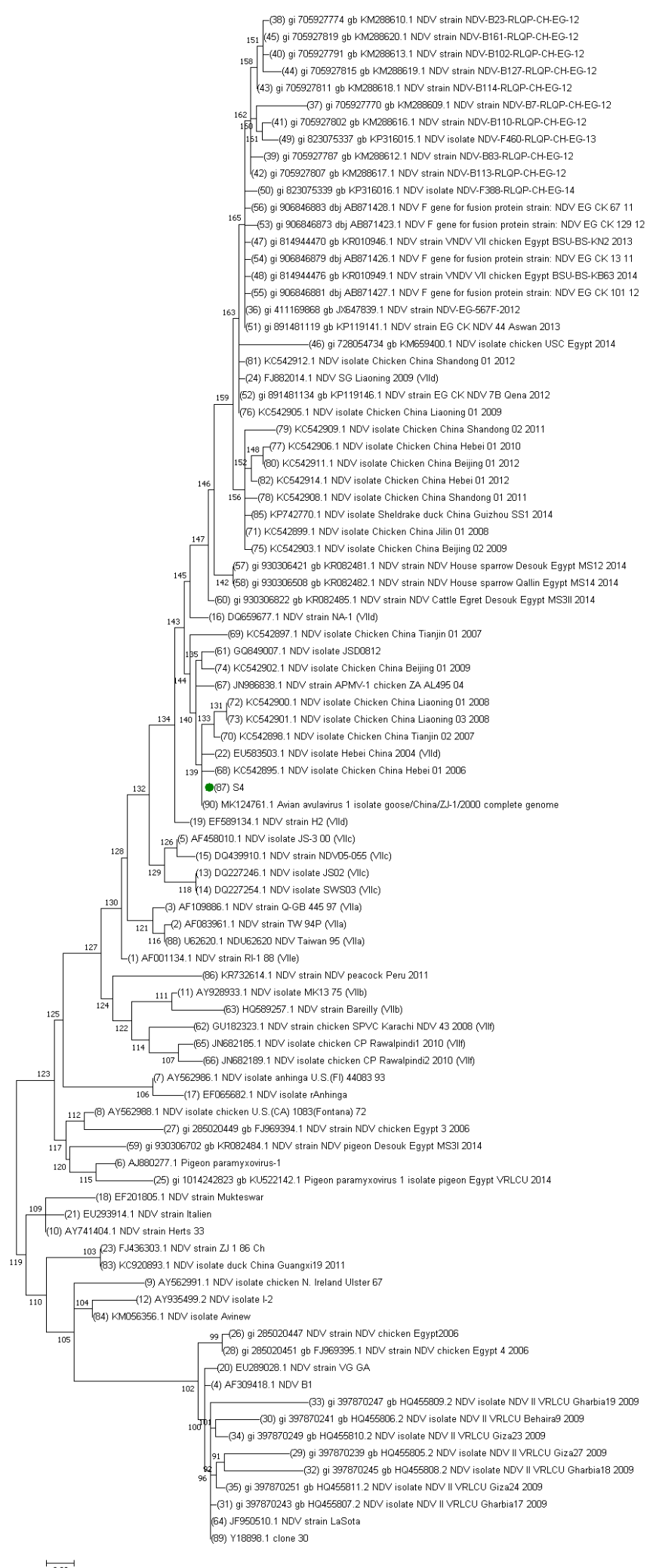

Figure 5. Neighbor-joining phylogenetic tree of the fulllength $\mathrm{F}$ gene of Egyptian isolate of Newcastle disease virus (NDV) (S4) in comparison to other NDV strains from GenBank. Bootstrap values are shown above the branches. S4 isolate is indicated by a solid green circle.

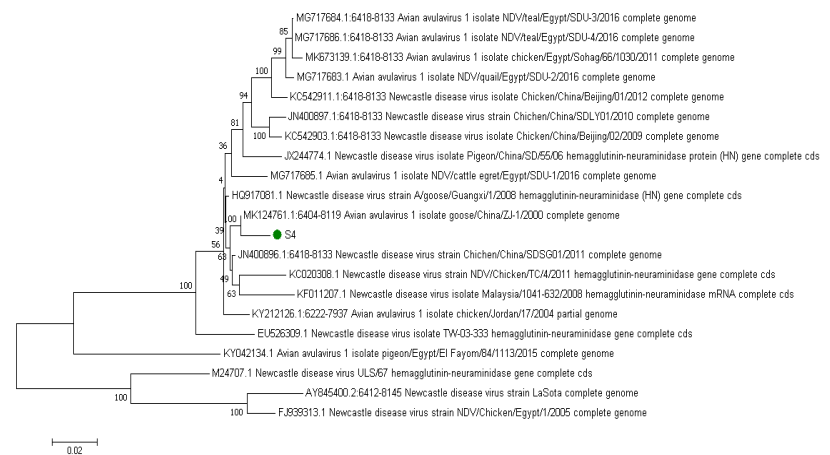

Figure 6. Neighbor-joining phylogenetic tree of the fulllength HN gene of Egyptian isolate of Newcastle disease virus (NDV) (S4) in comparison to other NDV strains from GenBank. Bootstrap values are shown above the branches. S4 isolate is indicated by a solid green circle.

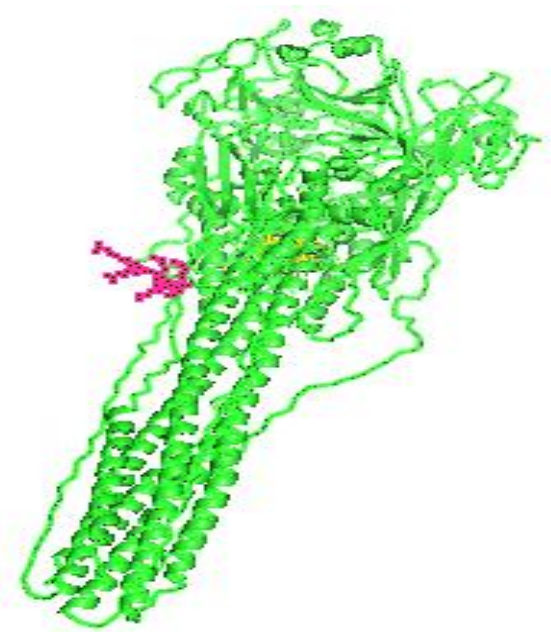

Figure 7. 3D structure for $\mathrm{F}$ protein of Newcastle disease virus (S4 isolate) created by SWISS-Model modeling online server and visualized by PyMOL program version 2.3.4, red color represents the cleavage site.

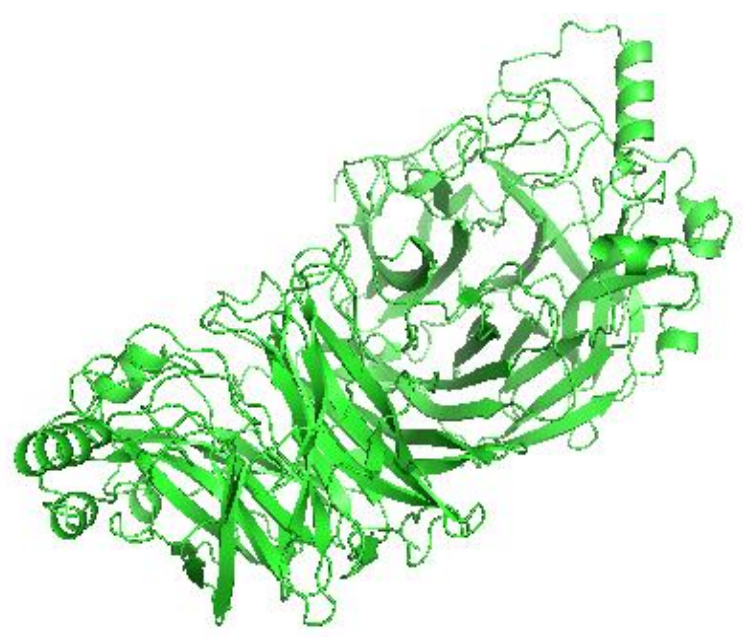

Figure 8. 3D structure for $\mathrm{HN}$ protein of Newcastle disease virus (S4 isolate) created by SWISS-Model modeling online server and visualized by PyMOL program version 2.3.4. 


\section{DISCUSSION}

In the current study, only five samples (50\% samples) showed HA positive activity indicating infection with a hemagglutinating virus. To confirm NDV infection, RTqPCR was performed using the HA positive samples.

Only S4 isolate was positive for NDV using universal primers for APMV-1. Negative RT-qPCR results for S3, S7, S9, and S10 may indicate an infection with another hemagglutinating virus-like avian influenza $\mathrm{H} 9$ or $\mathrm{H} 5$; however, history of mortalities and symptoms severity indicated H9 infection mixed with other respiratory pathogens other than H5 (Hussein et al., 2014; Sedeik et al., 2018). The most important pathogenicity indicator for $\mathrm{NDV}$ is the $\mathrm{F}$ protein gene sequence analysis mainly for cleavage site in which velogenic strains have polybasic amino acid sequences; therefore, molecular identification and phylogenetic analysis of the $\mathrm{F}$ gene is a major determinant

of NDV virulence instead of conventional methods (Mohamed et al., 2011; Damena et al., 2016). Also, it can be considered as a reliable way for NDV virulence evaluation when compared to traditional ways of evaluation (Ganar et al., 2014).

Results of $\mathrm{F}$ protein gene sequencing revealed that the cleavage site motif of $\mathrm{S} 4$ isolate has the sequence of velogenic NDV strains ${ }_{112} \mathrm{RRQKRF}_{117}$ in agreement with (Sedeik et al., 2019). Also, the neurological effects of NDV infections by is thought to be due to the presence of the phenylalanine $(\mathrm{F})$ residue at position 117 (Collins et al., 1993). The full sequence of both $\mathrm{F}$ and $\mathrm{HN}$ protein genes were submitted to the GenBank database with accession number MN905162 for the full F protein gene sequence and MN905163 for the full HN protein gene sequence.

$\mathrm{F}$ and $\mathrm{HN}$ proteins genes genetic and phylogenetic analysis in the present study revealed high similarity of S4 isolate with Chinese isolates and relatively fewer similarities with the Egyptian isolates which may strongly refer to the role of migratory wild birds in NDV evolution in Egypt.

\section{CONCLUSION}

Newcastle disease still occurs in sporadic cases despite massive vaccination programs implemented in the Egyptian poultry field. Migratory wild birds are supposed to have a big role in the continuous evolution of NDV in Egypt. Further epidemiological and surveillance work is strongly recommended to define the exact role of migratory wild birds in NDV evolution in Egypt with defining the main causes of the inability of currently used vaccines to protect chickens against infection with Newcastle disease virus.

\section{DECLARATION}

\section{Authors' contributions}

All authors reviewed the final manuscript. This work is a part of Mira Maher, and Abdulrahman S. Metwally thesis under the supervision of Shakal M, and Gehan Safwat. Shakal M. designed, supervised the experiments, and co-wrote the paper. Gehan Safwat co-designed the experiment and co-wrote the paper. Mohammed A. Abdel Sabour conducted samples pooling, virus isolation, and cowrote the paper. Mira Maher and Abdulrahman S. Metwally conducted RNA extraction, genes amplification by PCR, and conducted genetic alignment. Yahia M. Madbouly conducted RNA extraction, real-time reverse transcription PCR, GenBank submission, phylogenetic analysis, and co-wrote the paper.

\section{Competing interests}

The authors declare that they have no competing interests.

\section{Acknowledgments}

Authors gratefully acknowledge Dr. Mohammed Rohaim, Virology Department, Cairo University, Egypt for his kind support and comments.

\section{REFERENCES}

Abd El Aziz M, Abd El-Hamid H, Ellkany H, Nasef S, Nasr S, and El Bestawy A (2016). Biological and molecular characterization of Newcastle disease virus circulating in chicken flocks, Egypt, during 2014-2015. Zagazig Veterinary Journal, 44(1): 9-20. DOI: https://dx.doi.org/10.21608/zvjz.2016.7827.

Aldous EW, Mynn JK, Banks J, and Alexander DJ (2003). A molecular epidemiological study of avian paramyxovirus type 1 (Newcastle disease virus) isolates by phylogenetic analysis of a partial nucleotide sequence of the fusion protein gene. Avian Pathology, 32: 239-256. DOI: https://doi.org/10.1080/030794503100009783.

Ashraf A, Shah MSU, Habib M, Hussain M, Mahboob S, and Al-Ghanim $\mathrm{K}$ (2016). Isolation, identification and molecular characterization of highly pathogenic Newcastle disease virus from field outbreaks. Brazilian Archives of Biology and Technology, 59: e16160301. DOI: https://doi.org/10.1590/1678-4324-2016160301.

Collins MS, Bashiruddin JB, and Alexander DJ (1993). Deduced amino acid sequences at the fusion protein cleavage site of Newcastle disease viruses showing variation in antigenicity and pathogenicity. Archives of Virology, 128: 363-370. DOI: https://doi.org/10.1007/BF01309446.

Damena D, Fusaro A, Sombo M, Belaineh R, Heidari A, Kebede A, Kidane, M, and Chaka H (2016). Characterization of Newcastle disease virus isolates obtained from outbreak cases in commercial 
chickens and wild pigeons in Ethiopia. Springer Plus, 5: 476-453. DOI: https://doi.org/10.1186/s40064-016-2114-8.

Diel DG, Susta L, Cardenas Garcia S, Killian ML, Brown CC, Miller PJ, and Afonso CL (2012). Complete genome and clinicopathological characterization of a virulent Newcastle disease virus isolate from South America. Journal of Clinical Microbiology, 50:378-387. DOI: https://doi.org/10.1128/JCM.06018-11.

Dimitrov KM, Ramey AM, Qiu X, Bahl J, and Afonso CL (2016). Temporal, geographic, and host distribution of avian paramyxovirus 1 (Newcastle disease virus). Infection, Genetics and Evolution, 39: 22-34. DOI: https://doi.org/10.1016/j.meegid.2016.01.008.

Daubeny R. and Mansy W (1947). The occurrence of Newcastle disease in Egypt. Journal of Comparative Pathology and Therapeutics, 58: 189-200. DOI: https://doi.org/10.1016/S0368-1742(48)80019-6.

Ewies SS, Ali A, Tamam SM, and Madbouly HM (2017). Molecular characterization of Newcastle disease virus (genotype VII) from broiler chickens in Egypt. Beni-Suef University Journal of Basic and Applied Sciences, 6 (3): 232-237. DOI: https://doi.org/10.1016/j.bjbas.2017.04.004.

Fringe R, Bosman, AM, Ebersohn K, Bisschop S, Abolnik C, and Venter E (2012). Molecular characterisation of Newcastle disease virus isolates from different geographical regions in Mozambique in 2005. Onderstepoort Journal of Veterinary Research, 79 (1):409416. Available https://journals.co.za/content/opvet/79/1/EJC129097.

Ganar, K., Das, M., Sinha, S., Kumar, S (2014). Newcastle disease virus: current status and our understanding. Virus Research, 184: 71-81. DOI: https://doi.org/10.1016/j.virusres.2014.02.016.

Hall TA (1999). BioEdit: a user-friendly biological sequence alignment editor and analysis program for Windows 95/98/NT. Nucleic Acids Symposium Series, 41:95-98. Available at: https://www.scienceopen.com/document?vid=690e7265-f2ce-4d9c82a2-399cca46fbef.

Hassan KE, Shany SA, Ali A, Dahshan AH, El-Sawah AA, and El-Kady MF (2016). Prevalence of avian respiratory viruses in broiler flocks in Egypt. Poultry Science, 95 (6): 1271-1280. DOI: https://doi.org/10.3382/ps/pew068.

Hussein HA, Emara MM, Samy AM, and Shalaby MA (2000). Antigenic diversity of Newcastle disease virus isolated from 52 breeder and broiler flocks in Egypt.The Egyptian .J .of Imm .Vet, 2: 3-15. Available at Egyptian Journal of Veterinary Sciences http://www.members.tripod.com/ejimmunology/previous/jun00/jun 00-11.html.

Hussein AH, Emara MM, Rohaim MA, Ganapathy K, and Arafa AM (2014). Sequence analysis of infectious bronchitis virus IS/1494 like strain isolated from broiler chicken coinfected with Newcastle disease virus in Egypt during 2012. International Journal of Poultry $\begin{array}{llll}\text { Science, } & 13 & \text { (9): } & 530-536 .\end{array}$ http://dx.doi.org/10.3923/ijps.2014.530.536.

Jaganathan S, Ooi PT, Phang LY, Allaudin ZN, Yip LS, Choo PY, Lim BK, Lemiere S, and Audonnet JC (2015). Observation of risk factors, clinical manifestations and genetic characterization of recent Newcastle disease virus outbreak in West Malaysia. BMC Veterinary Research, 11: 219-227. DOI: https://doi.org/10.1186/s12917-015-0537-z.

Kang Y, Li Y, Yuan R, Li X, Sun M, Wang Z, Feng M, Jiao P, and Ren $\mathrm{T}$ (2014). Phylogenetic relationships and pathogenicity variation of two Newcastle disease viruses isolated from domestic ducks in Southern China. Virology Journal, 11: 147- 159. DOI: https://doi.org/10.1186/1743-422X-11-147.

Kattenbelt JA, Meers J, and Gould AR (2006). Genome sequence of the thermostable Newcastle disease virus (strain I-2) reveals a possible phenotypic locus. Veterinary Microbiology, 114: 134-141. DOI: https://doi.org/10.1016/j.vetmic.2005.10.041.

Marks FS, Rodenbusch CR, Okino CH, Hein HE, Costa EF, Machado G, Canal CW, Brentano L, and Corbellini LG (2014). Targeted survey of Newcastle disease virus in backyard poultry flocks located in wintering site for migratory birds from Southern Brazil. Preventive Veterinary Medicine, 116: 197-202. DOI: https://doi.org/10.1016/j.prevetmed.2014.06.001.

Mase M, Imai K, Sanada Y, Sanada N, Yuasa N, Imada T, Tsukamoto K, and Yamaguchi S (2002). Phylogenetic analysis of Newcastle disease virus genotypes isolated in Japan. Journal of Clinical Microbiology, $40: \quad 3826-\quad 3830 . \quad$ DOI: https://doi.org/10.1128/jcm.40.10.3826-3830.2002.

Mohamed MHA, Kumar S, Paldurai A, and Samal SK (2011). Sequence analysis of fusion protein gene of Newcastle disease virus isolated from outbreaks in Egypt during 2006. Virology Journal, 8: 237-240. DOI: https://doi.org/10.1186/1743-422X-8-237.

OIE Manual (2018). Newcastle Disease, Chapter 2.3.14. OIE, Paris. Available https://www.oie.int/fileadmin/Home/eng/Health_standards/tahm/3.0 3.14_NEWCASTLE_DIS.pdf.

Saad AM, Samy A, Soliman MA, Arafa A, Zanaty A, Hassan MK, and Hussein AH (2017). Genotypic and pathogenic characterization of genotype VII Newcastle disease viruses isolated from commercial farms in Egypt and evaluation of heterologous antibody responses. Archives of Virology, 162(7): 1985-1994. DOI: https://doi.org/10.1007/s00705-017-3336-y.

Sedeik ME, El-Shall, NA, Awad AM, and Kandil N (2018). Molecular survey and characterization of H5N8 isolates during 2016-2017 in Egypt. Journal of World's Poultry Research, 8 (4):127-133. Available at http://jwpr.scienceline.com/attachments/article/47/J\%20World\%20Poult\%20Res\%208 (4)\%20127-133,\%202018.pdf.

Sedeik ME, Nahed A El-Shall, Ashraf M Awad, Mohamed A Saif, and Hadeer D Elsayed (2019). Surveillance and molecular characterization of Newcastle disease virus from chickens in north Egypt during 2015-2017. Alexandria Journal of Veterinary Sciences, 62(2): 82-90. DOI: http://dx.doi.org/10.5455/ajvs.55709.

Koichiro T, Glen S, Daniel P, Alan F, and Sudhir K, MEGA6 (2013). Molecular Evolutionary Genetics Analysis Version 6.0. Molecular Biology and Evolution, 30 (12): 2725-2729. DOI: https://dx.doi.org/10.1093\%2Fmolbev\%2Fmst197.

Peeters BP, de Leeuw OS, Koch G, and Gielkens AL (1999). Rescue of Newcastle disease virus from cloned cDNA: evidence that cleavability of the fusion protein is a major determinant for virulence. Journal of Virology, 73:5001-5009. Available at: https://www.ncbi.nlm.nih.gov/pmc/articles/PMC112544/.

Selim KM, Selim A, Arafa A, Hussein HA, and Elsanousi AA (2018). Molecular characterization of full fusion protein (F) of Newcastle disease virus genotype VIId isolated from Egypt during 20122016. Veterinary World, 11(7) 930-938. DOI: https://doi.org/10.14202/vetworld.2018.930-938.

Shahid M, Muhammad Q, Al-Ghanim KA, Al-Misned F, and Al-Mulhim $\mathrm{N}$ (2020). Isolation, identification and molecular characterization of Newcastle disease virus using SDS-PAGE. Journal of King Saud University - Science, 32(1): 1000-1003. DOI: https://doi.org/10.1016/j.jksus.2019.09.005.

Wang JY, Liu WH, Ren JJ, Tang P, Wu N, Wu HY, and Liu H J (2015). Characterization of emerging Newcastle disease virus isolates in China. Virology Journal, 12(1): $119 . \quad$ DOI: https://doi.org/10.1186/s12985-015-0351-z.

Westbury HA (2001). Newcastle disease virus: an evolving pathogen. Avian Pathology, 30: 5-11. DOI https://doi.org/10.1080/03079450020023131.

Wise GM, David LS, Bruce SS, Janice CP, Dennis AS, Daniel JK, Darrell R K, and Erica S (2004). Development of a Real-Time reverse-transcription PCR for detection of Newcastle disease virus RNA in clinical samples. Journal of Clinical Microbiology, 42 (1) 329-338. DOI: https://doi.org/10.1128/JCM.42.1.329-338.2004. 